\title{
Analysis and Construction of Multidimensional Industry Chains of Agritourism
}

\author{
Shuai Mao*, Yang Song, Xiaolin Meng, Faroq Abdulkarem Ahmed \\ China University of Mining and Technology, P. R. China \\ China University of Mining and Technology, P. R. China \\ University of Nottingham, United Kingdom \\ China University of Mining and Technology, P. R. China
}

\begin{abstract}
Multiple influencing factors and multidimensional industry chains can lead to some difficulties in operations management of agritourism. Five industry chains have been established to analyze the multidimensional agritourism industrial chains, including the value chain, supply chain, product chain, technology chain and space chain. Firstly, in agritourism value chain, core competence has been created. Secondly, in agritourism product chain, three types products chains have been built and analyzed. Thirdly, in agritourism technology chain, the technologies used at every point of the chain have been discussed and lined. Fourthly, in agritourism supply chain, two main structures have been analyzed depending on whether there is deep-processed and transportation. Lastly, in agritourism space chain, the types have been drawn and discussed based on different types of nodes. On the basis of these analysis, we can achieve the overall planning of agritourism from the large economic region, which forms the characteristics of the operation and coordinated development in different regions and helps to solve the issues of residents' leisure, pension, livableness, environmental protection and so on.
\end{abstract}

Keywords-Agritourism; Construction; Industry Chains

\section{INTRODUCTION}

In 21st Century society, leisure activities, especially agritourism, have become major economic resources for nations worldwide. The leisure pursuits of the population although non-vital, discretionary activity - have grown to outline the unique characteristics of a specific culture (Connell and Page, 2010). Many European governments like Germany, France, the UK and some other countries like Japan and so on pay great attention to the construction of tourism infrastructure and provide policies in support of the development of tourism, especially agritourism. Take farmers from European Union countries as an example; they can receive great help from the promotion of rural development by the LEADER program (Cawley \& Gillmor, 2008).

Agritourism has developed rapidly worldwide and is now an important source of income for many countries. In Germany, farm tourism activities contribute between $25 \%$ and $35 \%$ of overall income (Katia Laura Sidali, Achim Spiller, Birgit Schulze, 2011. P. 5)

In short, thanks to the rapid development of leisure demands of residents, the increased attention from governments and the exploration of practitioners, agritourism all over the world has been able to develop quickly; the traditional agri-tourism industrial chain has been formed and a business model has been built. But today, new technologies and the Internet have hit many areas, including the management of agritourism, which is based on traditional agriculture. In this case, the industrial chain of agritourism must be integrated, extended and quickly developed.

This paper seeks to discuss the industrial chain of agritourism today from five points of view: value chain, supply chain, product chain, technology chain and space chain.

The field work undertaken here has, importance because it not only broadens the industrial chain of agritourism in order to form a whole chain in a big region, but can also help farmers find their "Optimal location" and help an economic area to find its own characteristics in the process of agritourism development. What's more, livable and environment protection and other issues can also be solved with the extension of agritourism industrial chain.

\section{STATE OF THE ART}

\section{A. Concept of agritourism}

With reference to agritourism studies, many researchers suggest that agritourism be described as visiting an agricultural region for recreational or educational purposes (Gil Arroyo, Barbieri, \& Rozier Rich, 2013; Ollenburg, \& Buckley, 2007). Agritourism including many types of activities like planting and harvest (e.g., fruit and vegetable planting, pick-your-own, fishing), recreational activities (e.g., general recreational activities, eating and living in houses of farmers'), educational activities based on nature and agriculture resources (e.g., wild life observation, farm tours) (Barbieri \& Mshenga, 2008; McGehee, Kim, \& Jennings, 2007; Tew \& Barbieri, 2012) and so on. Thus, agritourism includes different contexts and can meet different tourism motivations of visitors based on its agricultural resources (Valdivia \& Barbieri, 2014).

Thus, from this perspective, we will analyze the agritourism industrial chain mainly based on three kinds of classification: planting and harvest, recreational activities and educational activities based on big regions. 


\section{B. The conceptual framework of industry chain}

Industry is a concept which came from Industrial Economics; it is a chain form of association layout of a specific logic and spatiotemporal. Industry chain includes value chain, business chain, supply chain and space chain. The industry chain is formed in the process of equalization of the four dimensions.

(1)Value chain. A value chain is a set of activities that a firm operating in a specific industry performs in order to deliver a valuable product or service for the market. The concept came from business management and was firstly described and popularized by Michael Porter in his 1985 bestseller, Competitive Advantage: Creating and Sustaining Superior Performance (M. E. Poter, 1985).

(2)Business chain. Business chain is formed by the flow and interaction of products, money, technology and so on (Gosain, Malhotra, \& El Sawy, 2004). Since agritourism is mostly run by the farmers themselves, this study will therefore not explore the capital chain. As products and service are the most important aspects in agtitourism operation, and high technology impacted various areas including agritourism, such as products and service chain, the technology chain will be researched with value chain, supply chain and space chain.

(3)Supply chain. A supply chain is a system of organizations, people, activities, information, and resources involved in moving a product or service from the supplier to the customer (Mentzer et al., 2001). There are many activities involved in the supply chain like the transformation of natural resources and components into a finished product which is delivered to the final buyer. Sometimes, used products may reenter the system when they are recyclable (Anna Nagurney, 2006).

(4)Space chain. Space chain is the different distributions of an industry chain. There will be a new industry chain combined by nodes from different areas (Towill \& Christopher, 2010). Space chains are divided into three levels: global, national and regional.

These four chains all will be analyzed. For the business chain, since agritourism is mostly run by the farmers themselves, this study will therefore not explore the capital chain. As products and service are the most important aspects in agtitourism operation, and high technology impacted various areas including agritourism, such as products and service chain, the technology chain will be researched with value chain, supply chain and space chain. That is the fivedimensional industry chain of agritourism. chain

Methodology-The study setting of agritourism industrial

In this study, there are five chains which will be researched value chain, products and service chain, technology chain, supply chain and space chain. It is therefore multidimensional agritourism industry chain research.

TABLE I. DESCRIPTIONS OF FIVE VIEWS OF AGRITOURISM INDUSTRY CHAIN RESEARCH FRAMEWORK

\begin{tabular}{cll}
\hline Type of view & \multicolumn{1}{c}{ Primary focus } & Focus on agritourism \\
\hline Value chain & $\begin{array}{l}\text { a specific industry performs } \\
\text { choose the main product, form the product } \\
\text { chain }\end{array}$ & $\begin{array}{l}\text { create core competence of agritourism. } \\
\text { extend the agritourism product chain, care the } \\
\text { characteristic of a particular region }\end{array}$ \\
$\begin{array}{c}\text { technology } \\
\text { chain }\end{array}$ & $\begin{array}{l}\text { upstream and downstream } \\
\text { the technology in the product chain between the }\end{array}$ & $\begin{array}{l}\text { the the } \\
\text { and the relaitonship between the technology and } \\
\text { current technology }\end{array}$
\end{tabular}

supply chain a system of moving a product or service from supplier to customer the agritourism supply chain in the new background of new technology and internet+

space chain the different distributions of an industry chain

build a new agritourism space chain in a big region

(1)Research on agritourism value chain, aimed to analyze and create the core competence of agritourism based on its three main styles and on the whole agritourism industry chain. In Porter's value chains, the primary activities include Inbound Logistics, Operations, Outbound Logistics, Marketing and Sales, Service. Human Resource management, Procurement, Technological Development and Infrastructure are categorized as secondary activities (Porter, 1985, pp. 11-15). On the basis of this model, agritourism value chain will be researched.

(2)The production and consumption of goods involves the activities of a number of actors, and the relations between these actors (Boons, 2002). Product chain is the foundation and core of circular economy industrial chain. Research on agritourism product chain, aims to choose the main product, extend the product chain, and take into consideration the characteristic of a particular region. The agritourism product chain includes the existing product structure and product chain with development potential. For the existing agritourism product chain, rationality of the product structure should be analyzed and the main product chain should be extended and strengthened. For the potential agritourism product chain, the short-term easily achieved product chain should be paid more attention, and the cooperation between different regions should be analyzed. 
(3)An agritourism technology chain is formed by the technology which materialized in the agritourism product chain between the upstream and downstream. Sometimes, the agritourism product is produced by using many technologies and these technologies may have a series of relations. Sometimes, the use of a technology may have to use some of the upstream technology as a precondition. In the analysis of the agritourism technology chain, the technologies used in industrial agritourism products will be analyzed, and the relationship between the technology and current technology as a parallel relationship or link relationship will also be researched.

(4)Research on agritourism supply chain, is aimed at analyzing the system of delivering products or service from suppliers to visitors or customers especially with the boom of new technologies and internet+ (Baggio, Sigala, Inversini, Pesonen, \& Eds., 2013; Ammirato, Felicetti, Della Gala, Aramo-Immonen, \& Jussila, 2015).
(5)Research on agritourism space chain, is aimed at analyzing the different distributions of an agritourism industry chain and build the new agritourism space chain in a big region. The small area in this big region can then find their best locations and help each other to make more profit.

\section{ANALYSIS AND DISCUSSION}

\section{A. Agritourism Value Chain}

The agritourism value chain is a set of activities (goods and services) that a farm operating in a specific agirculture performs in order to deliver a valuable agricultural product or service for the market to the final customer or consumer. The concept has been used since the beginning of the millennium, primarily by those working in agricultural development in developing countries, although there is no universally accepted definition of the term.

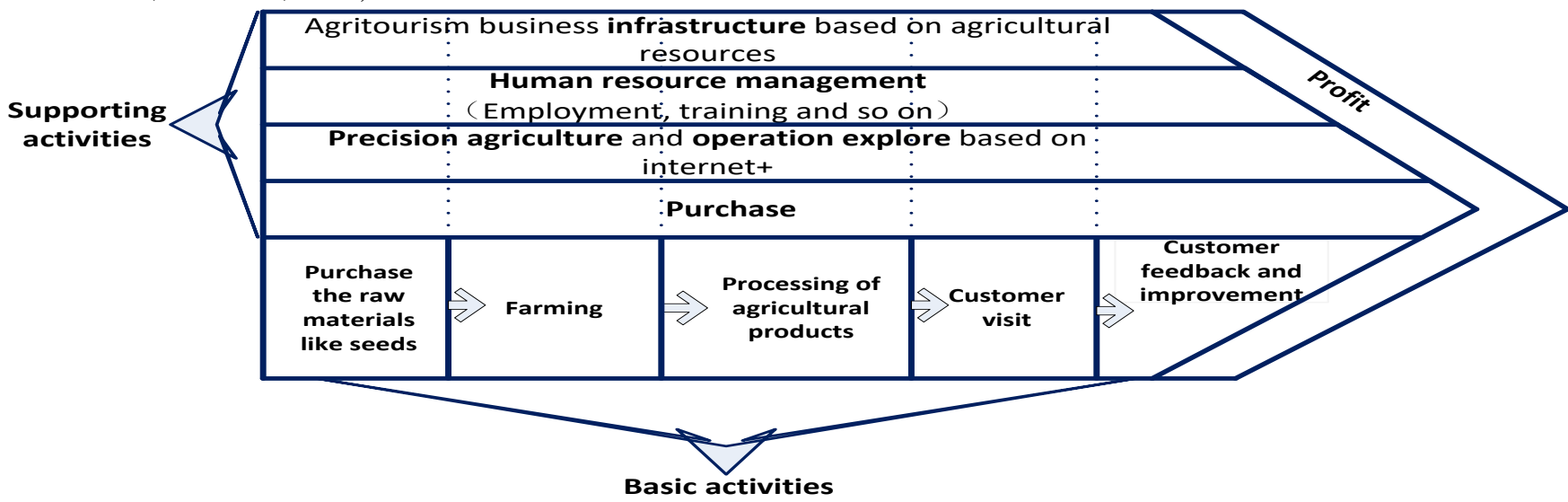

Fig. 1 Agritourism Value Chain

According to Fig. 1, supporting activities include agritourism business infrastructure based on agricultural resources, human resource management, precision agriculture and operation exploration based on internet+, and purchase.

The process of the basic activities starts from purchasing the raw materials like seeds, followed by the farming, processing of agricultural products, customer visit and customer feedback and improvement. In this process, the most important part is the customer visit. Customer tourism is the fundamental issue in the purpose of achieving economic benefits. Thus, the design and management of agritourism which can enhance customers' experience and feeling is the most important aspect.

The supporting activities include agritourism business infrastructure based on agricultural resources, human resource management, precision agriculture and operation exploration based on internet+, and purchasing Firstly, the infrastructure based on agricultural resources should not only include shops, restaurants, family hotels, comfort stations and leisure areas, but should also consider constructing an RV base to suit those who take self-guided tours. Secondly, the human resource management is very different between the East and the West. Nevertheless, the most important thing is to ensure the dominant position of the farmers. Whether it's the British villa, the French vineyards and farms, or the German agricultural park, leisure agricultural operations are subject to the farmers. The French mature leisure agriculture education aid system and government funding system in Germany and the UK are very useful in helping farmers to operate and manage the agritourism. Thirdly, internet+ has impacted a lot of areas, including agritourism. Under the background of this era, the related research not only in precision but also in operation should consider the factor of internet+ with the aim of meeting customers' needs and obtaining profit. Lastly, purchasing is an important link in making money. Here, the farmers need to enhance the feeling of customers, and should especially create their own selling point which is different from supermarkets and food markets. For example, Japanese agritourism products are using the selling point of "FOOD" and "GREEN". These words indicate that they provide all kinds of life and freshness agricultural products for the public and create a green ecological environment for the citizens. In addition, they maintain the ecological balance, preventing disaster, and other public functions. In short, in the final aim to ensure profit, the operators need to do well in both basic activities and supporting activities. 


\section{B. Agritourism product chain}

The product chain is the core and foundation of circular economy industrial chain. Through the processing of finishing and deep processing of raw materials and products, the farmers can not only enhance the added value of goods, but can also reduce the logistics consumption and reduce production costs. According to the structure of raw material, we can choose the leading products, extend the product chain and by-product chain. Evidently, agritourism resources are different in different regions. Therefore the product chain may be different in different regions.

Currently, scholars' research on product chain is mainly based on enterprises. For instance, professor of Northwestern University in USA, Philip Kotler, is the leader of this research. Philip Kotler researched the width, length, depth and relevance of product chain from the marketing perspective (Kotler \& Armstrong, 2010). Michael McGrath studied the development schedules of enterprise product line and coordination of similar product families and product lines (McGrath, 2000). Meyer M.H studied the relationship between the product family and enterprise core competence, then he found the way to enhance core competence for enterprises (Meyer \& Utterback, 1993).

However, Michael E Porter found that within the clusters which were formed by corporations and other entities linked to each other in a particular field, you can expedite the information of products, technology, market competition and adjust the product structure and product chain timely (Porter, 2011).

So, the agritousim product chain will be researched in a big region and adjusted by the different features in a particular area.

According to Fig. 2, the agritourism product chain mainly includes three sub product lines following six steps. The products of agritourism can be divided into three categories: plant, fish and small animals, and infrastructure.

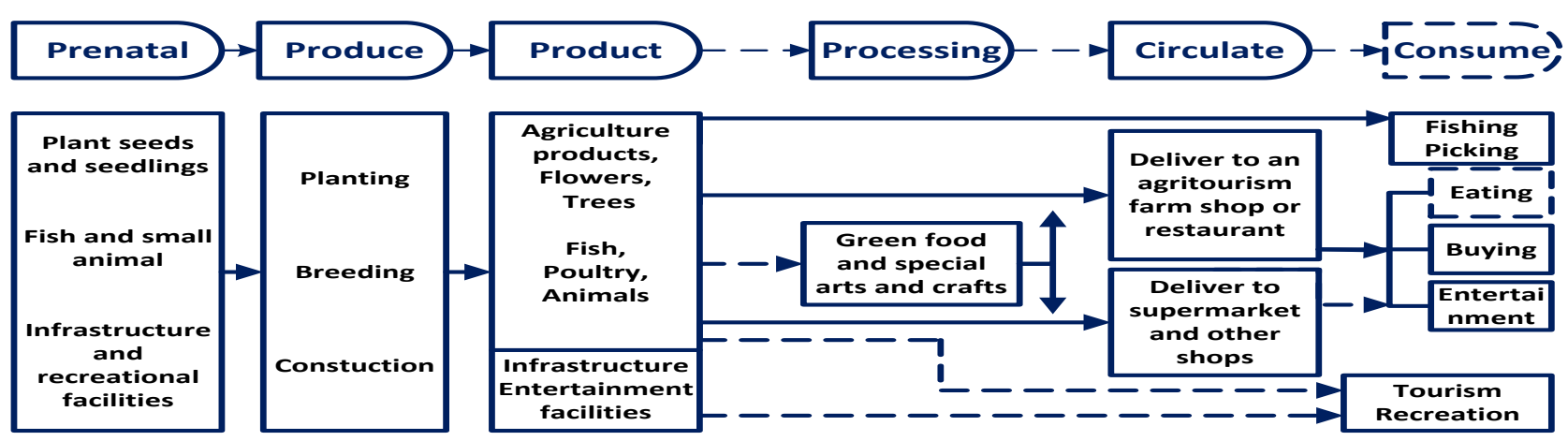

Fig. 2 Agritourism Product Chain

Both the breadth and depth of product mix can be optimized to suit the needs of customers.

The plant product chain starts from plant seeds and seedlings, then there is the planting, and after that we can gain agriculture products, flowers and trees. Customers can enjoy some of the plant products by picking them themselves. Some of the plant products are delivered to agritourism shops, restaurants and supermarketsand other shops far away.

The fish and animal chain starts from fish and small animal breeding, and after a period we can gain fish, poultry and animals. Customers can have tourism in the farm as well as fishing, feeding. Some of the fish and poultry can be cooked in farms, and some of them are delivered to agritourism shops, restaurants and supermarkets and other shops far away.

All agriculture products, such as flowers, trees and fish, poultry, animals can be processed into green food and special arts and crafts. These can be delivered to the agritourism farm shop or restaurant and supermarket and other shops outside the farms.

The third product chain is the chain of infrastructure facilities. It is the most simple chain. After design and construction, customers can entertainment themselves by using these facilities.

\section{Agritourism technology chain}

There are two kinds of technique chains: firstly, there may be a series of relations in the technologies, that is, to obtain a kind of technology we must use another kind of technology in the first place, then a link in related technologies is formed; secondly, products reflect the linked relations from upstream to downstream, thus, various technologies materialized in the products from upstream to downstream form a technology chain. The agritourism technology chain undoubtedly is the second position in the chain.

As in figure 3, different technologies will be used in each link of the agritourism industry chain and different technologies will be used in different products on each link of the agritourism industry chain too. Sometimes, the production of a product is the result of a variety of techniques and the technology of the product forms a chain based on the relationship between the upstream and downstream of the product. Sometimes, the use of some upstream technology must be used in relation to the use of other techniques. This means that, technologies themselves have the series of relations. 
Both the breadth and depth of product mix can be optimized to suit the needs of customers.

The plant product chain starts from plant seeds and seedlings, then there is the planting, and after that we can gain agriculture products, flowers and trees. Customers can enjoy some of the plant products by picking them themselves. Some of the plant products are delivered to agritourism shops, restaurants and supermarketsand other shops far away.
The fish and animal chain starts from fish and small animal breeding, and after a period we can gain fish, poultry and animals. Customers can have tourism in the farm as well as fishing, feeding. Some of the fish and poultry can be cooked in farms, and some of them are delivered to agritourism shops, restaurants and supermarkets and other shops far away.

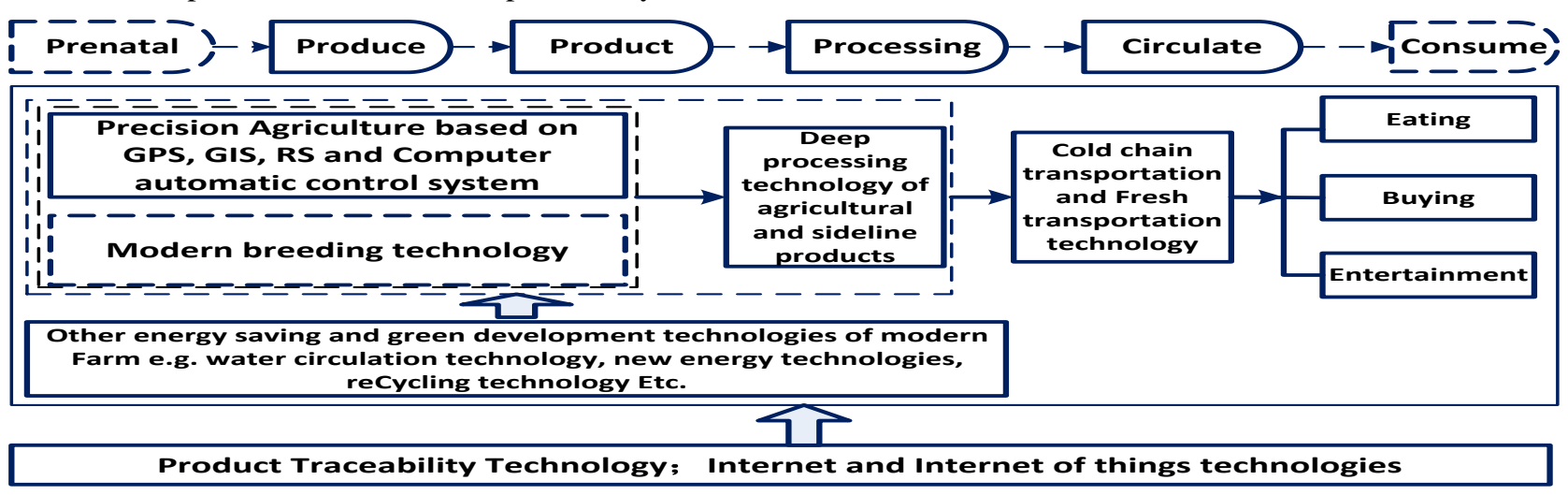

Fig. 3 Agritourism Product Chain

All agriculture products, such as flowers, trees and fish, poultry, animals can be processed into green food and special arts and crafts. These can be delivered to the agritourism farm shop or restaurant and supermarket and other shops outside the farms.

The thirThus, the structure of the technology chain is extremely complex. In order to describe the agritourism technology chain clearly, we use the production process as the axis, then add the current main technologies on the important points in the axis.

As we can see from figure 3 , in the first three steps of prenatal, produce and product, we may use the technologies of precision agriculture based on GPS, GIS, RS and the computer automatic control system(Lal, 2015). After that we may use the deep processing technologies of agricultural and sideline products at the processing stage (Afroj, Kazal, \& Rahman, 2016). The first four steps may be based on other energy saving and green development technologies of modern farm, like water circulation technology, new energy technologies, recycling technology and so on. Then, at the circulation stage, we may use the cold chain transportation and fresh transportation technology. The last step is consuming by eating, buying and enjoy. All of these are based on product traceability technology, internet and internet of things technologies (Sparkes \& Thomas, 2001; Stamboulis \& Skayannis, 2003).

We find that the technology chain is very important as it determines the industrial chain and value chain. The technology used at every point of the chain may determine the type of product, market structure and competitive situation, and then determine the value of that point of link. The agritourism technology chain is indeed a necessary condition for the formation of complete agritourism industrial chain. The characters of labor intensive, capital intensive or knowledge intensive determine the core link and the value distribution of the industry chain. Take precision agriculture as an example, it can improve the production, achieve the same income or higher income with minimum investment or maximum savings, and achieve economic and environmental benefits.

\section{Agritourism supply chain}

Supply chains are very different in different industry and enterprises. The agritourism supply chain is a part of the agritourism product chain. The agritourism supply chain is mainly described as the product transformed from a single enterprise. The scope involved is only the upper and lower reaches of the core enterprise in the supply chain. The main part of agritourism supply chain contains enterprise, farms, related suppliers, distributors and users.

d product chain is the chain of infrastructure facilities. It is the mostsimple chain. After design and construction, customers can entertainment themselves by using these facilities.

\section{E. Agritourism technology chain}

There are two kinds of technique chains: firstly, there may be a series of relations in the technologies, that is, to obtain a kind of technology we must use another kind of technology in the first place, then a link in related technologies is formed; secondly, products reflect the linked relations from upstream to downstream, thus, various technologies materialized in the products from upstream to downstream form a technology chain. The agritourism technology chain undoubtedly is the second position in the chain.

As in figure 3, different technologies will be used in each link of the agritourism industry chain and different 
technologies will be used in different products on each link of the agritourism industry chain too. Sometimes, the production of a product is the result of a variety of techniques and the technology of the product forms a chain based on the relationship between the upstream and downstream of the product. Sometimes, the use of some upstream technology must be used in relation to the use of other techniques. This means that, technologies themselves have the series of relations.

As for the agritourism supply chain, there are two main structures. Firstly, there is no transformation in the chain; customers consume just in the farm as in figure 4. Secondly, products will be deep-processed and transported to stores and supermarkets as in figure 5.

As we can see from figure 3, the agritourism supply chain begins with the means of production provider, followed by the agritourism farm, logistics enterprises, middleman, retailer and customer. Sometimes, the products from farms may be processed by enterprises, and delivered to the middleman, then retailer and in the end reaching the customers. The upper reaches of the agritourism supply chain are mainly means of production providers, the downstream reaches are mainly dealers and retailers from planning, procurement, and manufacturing, to distribution and withdrawal.

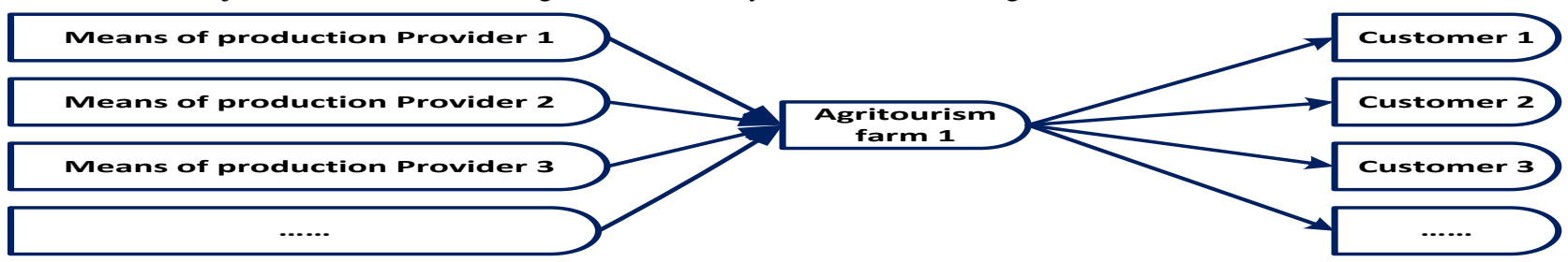

Fig. 4 Form 1 of Agritourism Supply Chain

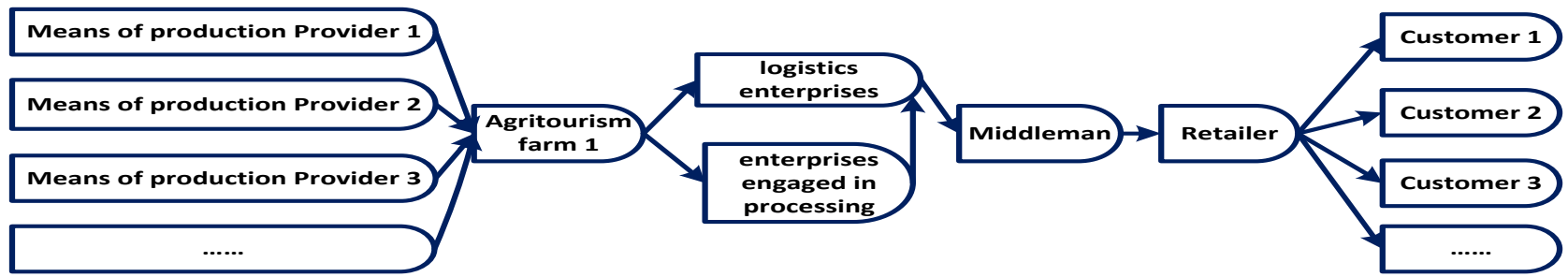

Fig. 5 Form 2 of Agritourism Supply Chain

The agritourism space chain refers to the distribution of the same industry chain in different regions. There are different distributions in different places for the same industry chain and there is also a situation in which a new industrial chain is formed between the links of industrial chains in different regions. As for agritourism, in the planning of its development blueprint we need to consider the optimization of resources and the coordinated development in large areas. So here, we carry out the research of the agritourism space chain in a big region.

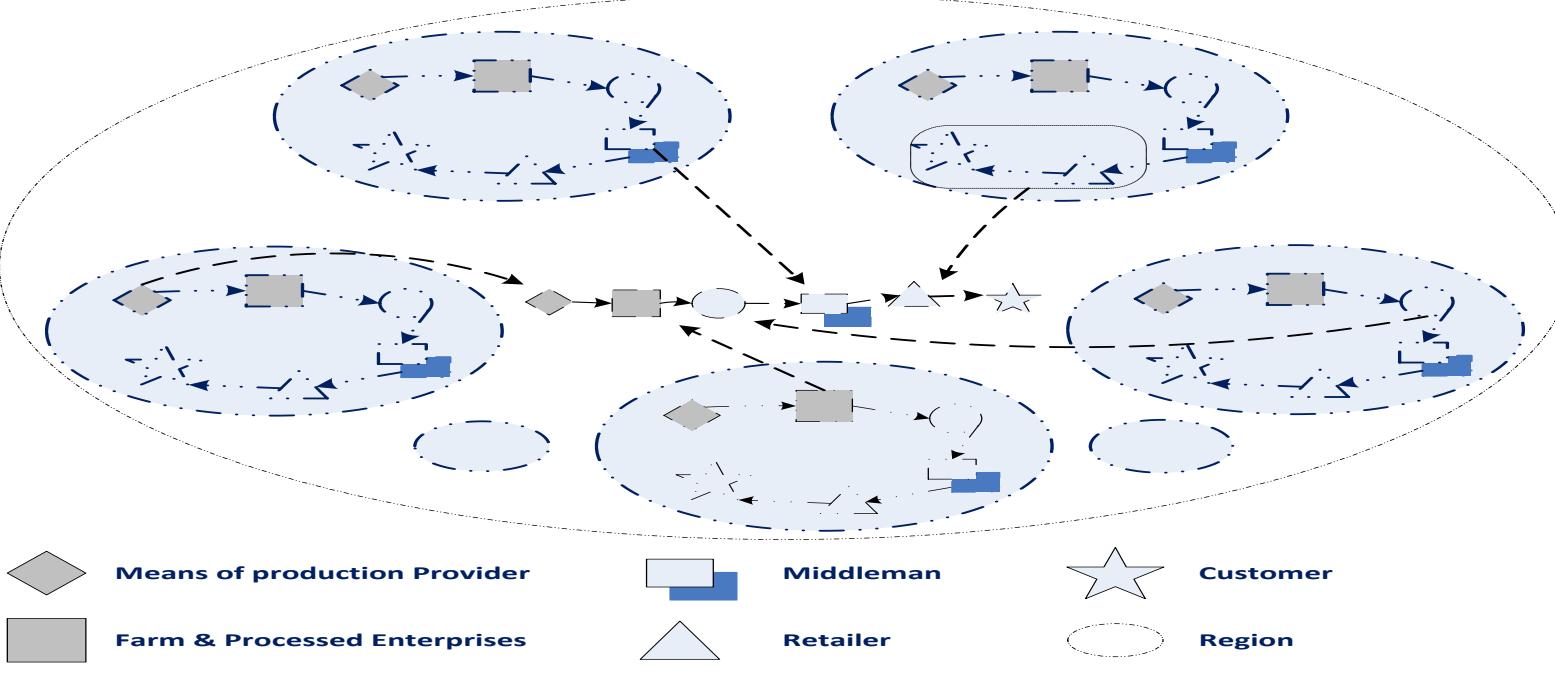

Logistics enterprises

Fig. 6 Agritourism Space Chain 
Normally, the space chain can be divided into three categories: global, national and regional. The development of these three levels of space chain should be coordinated. Thus, in the macroeconomic perspective, the chain is completed, but from the perspective of regional economy, the chain is not completed. This means that, when the economic division is on a large scale, such as economic zones, provincial or River Economic Zone, almost all aspects of the industry chain of the geographical space are included, and the industrial chain's integrity is clearly shown; when the economic division scale is in a small region, for example, just the city or the industry focus is on the development of one county area, then it is difficult to include all sectors of the industry chain. It forms a characteristic industry for a regional economy, but the industrial chain has shown obvious discontinuity.

In the agritourism space chain, the dockings of the main chain are divided into three conditions: first is the docking of nodes between different industrial chains; second is the docking of part of the industry chain and part of another chain; third is the joining of several whole industry chains to form a new one. However, it is rare to see the third case. So, figure 6 shows the agritourism space chain like case one and case two, some nodes or some part of the agritourism industry chains forms a new chain.

As we can see from figure 6 the agritourism space chain is one of the driving forces of the formation of agritourism industrial agglomeration. If the agritourism industry chain has the characteristic of concentration, it will form the agglomeration.

Each ring on the industrial chain is always settled to a certain region from the space, which means that each dock on the chain of the whole industrial chain must belong to a certain economic region from the spatial attribute.

In the macroeconomic perspective, the agritourism chain is basic and complete, but the specific economic region may have a complete chain, or only a part of the chain, even one or two links. In general, the relationship between the internal regional type and industry chain in the less developed regions generally have the up industry chain dock and the developed area always owns the downstream link.

\section{CONCLUSION AND EXPECTATION}

From the five dimensions analysis above, we can see that the key elements which impact the agritourism industry chain mostly are technical progress, the extension of the industrial chain, and the affluence of the product mix. In the future, we can extend the agritourism industrial chain in two ways. Firstly, extend the upstream including broadening the basic agriculture and enriching the leisure agriculture technology. Secondly, extend the downstream including enriching the product form, increasing the added value of products and expanding the market.

We also can see that, the agritourism industry chain is complete in the large economic zone or the basin economic zone. For an economic region, it is likely to form a special industry, but the industry chain has shown a significant intermittent.
We have to integrate the value chain, supply chain, product chain, technology chain and space chain of leisure agriculture, and optimize the formation of the multidimensional industrial chain model of agritourism. Then we can help the participants find their "excellent location" in the agritourism industry chain and "evidence and reasoning" in the process. Finally, we can achieve the overall planning of agritourism from the large economic region, form the characteristics of the operation and coordinated development in different regions and help solve the residents' leisure, pension, livableness, environmental protection and other issues.

\section{ACKNOWLEDGEMENTS}

Many thanks to the reviewers of this paper, the valuable comments given by them ensured this paper to be a good reference in the agritourism research area. This research is supported by Humanities and Social Science Foundation of Ministry of Education of China (NO. 14YJC630097).

\section{REFERENCES}

[1] Afroj, M., Kazal, M. M. H., \& Rahman, M. M. (2016). Precision agriculture in the World and its prospect in Bangladesh. Research in Agriculture Livestock and Fisheries, 3(1), 1-14.

[2] Ammirato, S., Felicetti, A. M., Della Gala, M., Aramo-Immonen, H., \& Jussila, J. (2015). Knowledge management and emerging collaborative networks in tourism business ecosystems. In Academic Conferences International Limited (pp. 19-26).

[3] Baggio, R., Sigala, M., Inversini, A., Pesonen, J., \& Eds. (2013). Information and Communication Technologies in Tourism 2014. eProceedings of the ENTER 2014 PhD Workshop, 1-146. http://doi.org/10.1007/978-3-319-03973-2

[4] Barbieri, C., \& Mshenga, P. M. (2008). The role of the firm and owner characteristics on the performance of agritourism farms. Sociologia Ruralis, 48(2), 166-183. http://doi.org/10.1111/j.14679523.2008.00450.x

[5] Boons, F. (2002). Greening products: A framework for product chain management. Journal of Cleaner Production, 10(5), 495-505. http://doi.org/10.1016/S0959-6526(02)00017-3

[6] Cawley, M., \& Gillmor, D. A. (2008). Integrated rural tourism:. Concepts and Practice. Annals of Tourism Research, 35(2), 316-337. http://doi.org/10.1016/j.annals.2007.07.011

[7] Gil Arroyo, C., Barbieri, C., \& Rozier Rich, S. (2013). Defining agritourism: A comparative study of stakeholders' perceptions in Missouri and North Carolina. Tourism Management, 37, 39-47. http://doi.org/10.1016/j.tourman.2012.12.007

[8] Gosain, S., Malhotra, A., \& El Sawy, O. A. (2004). Coordinating for flexibility in e-business supply chains. Journal of Management Information Systems, 21(3), 7-45.

[9] Kotler, P., \& Armstrong, G. (2010). Principles of marketing. pearson education.

[10] Lal, R. (2015). 16 Challenges and Opportunities in Precision Agriculture. Soil-Specific Farming: Precision Agriculture, 22, 391.

[11] McGehee, N. G., Kim, K., \& Jennings, G. R. (2007). Gender and motivation for agri-tourism entrepreneurship. Tourism Management, 28(1), 280-289. http://doi.org/10.1016/j.tourman.2005.12.022

[12] McGrath, M. (2000). Product strategy for high technology companies. McGraw Hill Professional.

[13] Mentzer, J. T., DeWitt, W., Keebler, J. S., Min, S., Nix, N. W., Smith, C D., \& Zacharia, Z. G. (2001). Defining supply chain management. Journal of Business Logistics, 22(2), 1-25.

[14] Meyer, M. H., \& Utterback, J. M. (1993). The product family and the dynamics of core capability. Sloan Management Review, 34(3), 29.

[15] Porter, M. E. (2011). Competitive advantage of nations: creating and sustaining superior performance. Simon and Schuster. 
[16] Sparkes, A., \& Thomas, B. (2001). The use of the Internet as a critical success factor for the marketing of Welsh agri-food SMEs in the twentyfirst century. British Food Journal, 103(5), 331-347.

[17] Stamboulis, Y., \& Skayannis, P. (2003). Innovation strategies and technology for experience-based tourism. Tourism Management, 24(1), $35-43$.

[18] Tew, C., \& Barbieri, C. (2012). The perceived benefits of agritourism: The provider's perspective. Tourism Management, 33(1), 215-224. http://doi.org/10.1016/j.tourman.2011.02.005.

[19] Towill, D., \& Christopher, M. (2010). The Supply Chain Strategy Conundrum: To be Lean or Agile or To be Lean And Agile? International Journal of Logistics, 5567(October 2013), 37-41. http://doi.org/10.1080/1367556021000026736.

[20] Valdivia, C., \& Barbieri, C. (2014). Agritourism as a sustainable adaptation strategy to climate change in the Andean Altiplano. Tourism Management Perspectives, 11, 18-25. http://doi.org/10.1016/j.tmp.2014.02.004. 